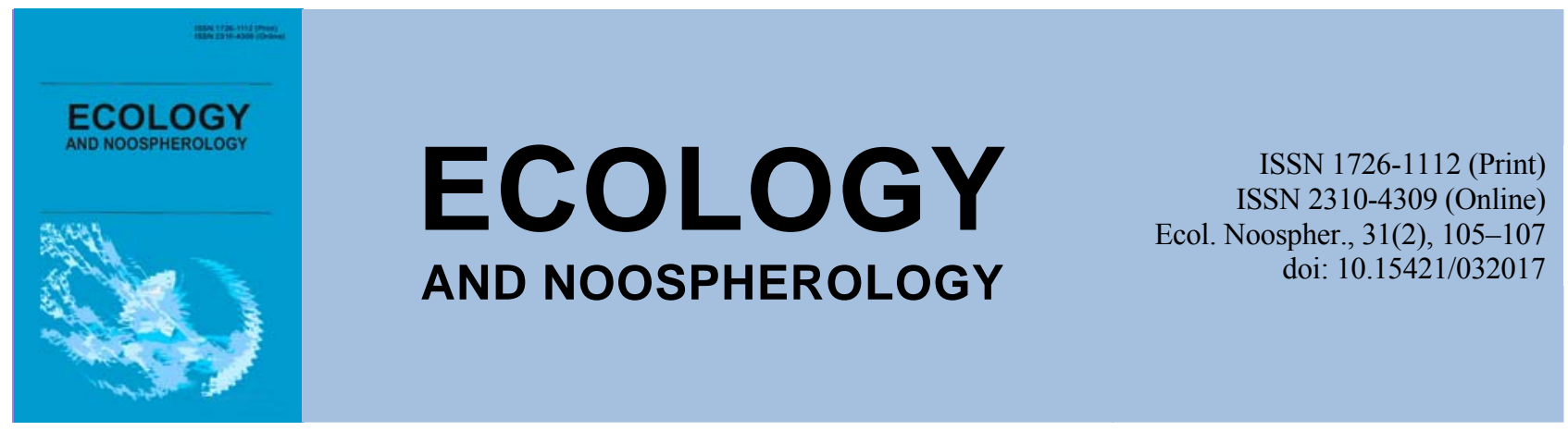

\title{
Characteristics of bottom fauna of small reservoirs of the Steppe zone of Ukraine
}

\author{
J. L. Poleva \\ Dnipro State Agrarian and Economic University, Dnipro, Ukraine
}

Article info

Received 03.10.2020

Received in revised form

12.10.2020

Accepted 17.10.2020

Dnipro State Agrarian and Economic University,

st. Serhiy Yefremov 25a,

Dnipro, 49600, Ukraine.

Tel.: +38067-956-06-36

E-mail:poyuliap@gmail.com
Poleva, J. L. (2020). Characteristics of bottom fauna of small reservoirs of the Steppe zone of Ukraine. Ecology and Noospherology, 31(2), 105-107. doi:10.15421/032017

The article is devoted to the study of the bottom fauna of small reservoirs of the Steppe zone of Ukraine and the search for approaches aimed at increasing fish productivity. The need to increase the fish productivity of reservoirs has put on the agenda the problem of increasing and improving the forage resources of fish. Increasing fish productivity by increasing stocks of industrially valuable fish species is possible by expanding aquatic invertebrate habitats by acclimatizing or relocating them to new reservoirs, introducing new species into all parts of the food chain that use food resources of reservoirs, i.e. by reconstructing benthic fauna. The main solution to this problem is the introduction and acclimatization of valuable forage aquatic invertebrates. Despite the fact that Ukraine has a very significant fishery fund of freshwater reservoirs, the state of many fisheries enterprises at the present stage is characterized by a decrease in production. The decline in fisheries production is largely due to a set of interrelated socio-economic and environmental limiting factors that emerged during the transition to market relations. The urgency of the problem and the biological productivity of water bodies are determined by the activity of aquatic organisms - an important part of which is the benthic fauna. Rational use of water bodies plays a significant role in the development of the country's economy and the preservation of the ecological situation.

Keywords: protection and restoration of reservoirs; benthic fauna; fish productivity; reservoirs; ecological factors

\section{Introduction}

The subject of hydrobiological research is ecological processes in the aquatic environment, i.e., the processes of interaction of aquatic organisms, their populations and communities with each other, as well as with abiotic components of aquatic ecosystems. The goal of hydrobiology can be defined as the understanding of ecological processes occurring in the aquatic environment, as well as the management of these processes in order to optimize the use of water and biological resources (Gritsinyak, 2008). The main task of our hydro-ecological research is to study ecological processes in the hydrosphere and apply the knowledge gained in the interests of developing the hydrosphere and optimizing the interaction of human society with aquatic ecosystems (Poleva, 2005). The main theoretical task of our research is to study the general internal laws of the structural and functional organization of aquatic ecosystems, which determine the circulation of matter and the flow of energy in them, as well as to study the dependences of the cycles of matter and energy flows on environmental factors, including anthropogenic ones. Work to increase the fish productivity of water bodies should be based on knowledge of their fauna and flora, biological, chemical, ecological, physiological and production properties of invertebrates and their requirements for environmental conditions. In addition, a prospective assessment of the feasibility of introducing food objects into the planned water bodies is impossible without knowledge of the biology and ecology of the introduced organisms (Zhuravel, 1947). The practical tasks of hydro-ecological research are to increase the biological productivity of reservoirs to obtain biological raw materials from the largest amount of them, to develop the biological foundations for providing people with clean water, including - to optimize the functioning of ecosystems created for the industrial purification of drinking and waste water, expert assessment of the environmental consequences of regulation, redistribution and transfer of river runoff, anthropogenic changes in the hydrological regime, assessment of newly created industrial, agricultural and other enterprises for aquatic ecosystems in order to protect the latter from unacceptable damage, monitoring the state of aquatic ecosystems (Sherman, 1992; Grinzhevsky, 2006).

\section{Material and methods}

The study areas are the Karachunovskoe, Nikolaevskoe and Sholokhovskoe reservoirs. The main method of hydrobiology, like other ecological disciplines, is the systems approach, that is, the consideration of the ecosystem as a whole and the quantitative accounting of the flows of energy, matter and information flowing in it (Kobyakov, 2020). Consequently, hydrobiology always operates with the values of the number of organisms, their biomass and 
production (Israel, 1984). For quantitative accounting, various tools and instruments are used, both specifically hydrobiological plankton nets, bottom grabs, dredges, bathometers of various designs, and many instruments borrowed from the arsenals of hydrochemistry, hydrophysics, and hydrology (Zagubizhenko, 1980). Recently, submersible and remote biophysical devices are often used. The ground was visually described on site. The collected material of the bottom fauna was washed through a benthic sieve made of silk mill gas, after which the material was placed in glass jars and fixed with a $4 \%$ formalin solution.

\section{Results and discussion}

The investigated reservoirs are located in the Dnipropetrovsk region of the Steppe zone of Ukraine, in the central steppe zone, located in the Black Sea depression, where the climate is temperate continental with a rather hot summer, when the greatest amount of precipitation falls in a year and in winter, accompanied by frequent thaws (Zagubizhenko, 1980, Ivanov, 2013). Considering the soil cover of the drainage areas of the studied water bodies, I would like to note the abundance of organic nutrients (Drake, 1994,). Speaking about forest plantations, I would like to note their insignificant presence they are located mainly in river valleys and the predominant tree species are oak, aspen, willow, alder, euonymus, etc. The general characteristics of reservoirs and the chemical composition of water are presented in Tables 1 and 2, also when describing the physicochemical and hydrobiological characteristics of the studied reservoirs, works were used.

\section{Microflora}

Karachunovskoye reservoir is represented by saprophytic bacteria (the number of bacteria decomposing proteins up to 9.6 thousand cells $/ \mathrm{ml}$ ), in Nikolaevskoye the presence of saprophytic bacteria was also noted (2.3-2.9 thousand cells $/ \mathrm{ml}$ of water), in Sholokhovskoye - denitrifiers represented by a small amount.

\section{Phytoplankton}

Karachunovsky - quite diverse and is represented by bluegreen (Aphanizomenon, Microcystis), diatoms (Asterionella, Fragilaria), protococcal (Ankistrodesmus) algae; Nikolaevsky protococcal algae (Ankistrodesmus) dominated - up to $50 \%$, the presence of euglena (Euglenoidea) algae indicates an increased content of organic matter in the reservoir; Sholokhovsky - among the blue-green algae, the most widespread group of phytoplankton were (Microcystis), which cause water "bloom"; in a small number, diatoms (Diatomeae) and euglena (Euglenoidea) algae developed.

\section{Zooplankton}

Karachunovskoe - cladocera and copepods (Cladocera, Copepoda) crustaceans; Nikolaevskoe - cladocerans, copepods (Cladocera, Copepoda) crustaceans (cyclops); Sholokhovskoe mainly cladocera predominate.

\section{Table 1}

General Characteristics of Reservoirs

\begin{tabular}{|c|c|c|}
\hline Reservoir name & Geographical position & Characteristic reservoir \\
\hline Karachunovskoe & $\begin{array}{l}\text { R. Ingulets, a tributary of } \\
\text { the Dnieper River - slightly } \\
\text { higher than the city of } \\
\text { Krivoy Rog }\end{array}$ & $\begin{array}{l}\text { Over } 5000 \text { hectares, the depth at the dam is up to } 20 \mathrm{~m} \text {, the shore } \\
\text { is slightly sloping, the soil is silted sand, the overgrowth of higher } \\
\text { aquatic vegetation near the coast is weak, the left bank is low - at } \\
\text { a depth of silty bottom soils, the banks of the dam part are used for } \\
\text { crops and pastures, on there are wooded areas on the left bank }\end{array}$ \\
\hline Nikolaevskoe & R. Tomakovka & $\begin{array}{l}\text { Over } 560 \text { hectares, the lower part of the reservoir was overgrown } \\
\text { with rough emergent vegetation, in the upper part of the reservoir } \\
\text { there were abundant thickets of common reed (Phragmites } \\
\text { australis), in the middle part of the reservoir, amphibian } \\
\text { buckwheat (Polygonum amphibium) }\end{array}$ \\
\hline Sholokhovskoe & R. Bazavluk & $\begin{array}{l}\text { The area is } 1500 \text { hectares, the depth is up to } 16 \mathrm{~m} \text {, there are high } \\
\text { rocky shores in the dam area. The reservoir is almost devoid of } \\
\text { above-water higher vegetation (rarely met - Butomus umbellatus, } \\
\text { Alisma plantago) }\end{array}$ \\
\hline
\end{tabular}

Table 2

Characterization of Chemical Indicators of Water

\begin{tabular}{|c|c|c|c|c|}
\hline Reservoir Name & $\begin{array}{l}\text { Active reaction } \\
\text { of water }\end{array}$ & $\begin{array}{l}\text { Amount of free } \\
\text { carbon dioxide }\end{array}$ & Biogenic substances & Mineralization of water \\
\hline Karachunovskoe & $\begin{array}{l}\text { Weakly alkaline } \\
\text { and alkaline - } \\
\mathrm{pH}=7.9-8.8\end{array}$ & $\begin{array}{l}\text { From } 0 \\
\text { to } 3.96 \mathrm{mg} / 1\end{array}$ & $\begin{array}{l}\text { There were biogenic } \\
\text { substances } \\
(\mathrm{NH} 4-0.01-0.8 \mathrm{mg} / \mathrm{l} \\
\mathrm{NO} 2-\text { up to } 0.07 \mathrm{mg} / \mathrm{l})\end{array}$ & $\begin{array}{l}\text { Increased, the concentration } \\
\text { of ions reached } 770 \mathrm{mg} / \mathrm{l}\end{array}$ \\
\hline Nikolaevskoe & $\begin{array}{c}\text { Weakly alkaline - } \\
\text { alkaline }- \\
\text { pH }=7.2-8.2\end{array}$ & $\begin{array}{l}\text { From } 0 \\
\text { to } 4.4 \mathrm{mg} / \mathrm{l}\end{array}$ & $\begin{array}{l}(\mathrm{NH} 4-0.048-0.094 \mathrm{mg} / \mathrm{l}, \\
\mathrm{NO} 2-\text { up to } 0.082 \mathrm{mg} / \mathrm{l}) \\
\text { phosphorus and iron up to } \\
0.1 \mathrm{mg} / \mathrm{l}\end{array}$ & $\begin{array}{l}\text { Mineralization of water - } \\
\text { high, the concentration of } \\
\text { ions was } 1618-1962 \mathrm{mg} / \mathrm{l}\end{array}$ \\
\hline Sholokhovskoe & $\begin{array}{c}\text { Weakly alkaline - } \\
\text { alkaline - } \\
\mathrm{pH}=7.5-8.15\end{array}$ & $\begin{array}{l}\text { From } 0 \\
\text { to } 2.2 \mathrm{mg} / 1\end{array}$ & Insignificant amount & $\begin{array}{l}\text { High mineralization of water- } \\
1136-1206 \mathrm{mg} / \mathrm{l}\end{array}$ \\
\hline
\end{tabular}

\section{Ichthyofauna}

Karachunovskoe - bream (Abramis brama), pike perch (Sander lucioperca), carp (Cyprinus carpio), pike (Esox
Lucius), perch (Perca fluviatilis), roach (Rutilus rutilus); Nikolaevskoe - bream (Abramis brama), pike perch (Sander lucioperca), carp (Cyprinus carpio); Sholokhovskoe - the fish fauna includes bream (Abramis brama), pike perch (Sander 
lucioperca), perch (Perca fluviatilis), roach (Rutilus rutilus), carp (Cyprinus carpio), the main fishery is carried out at the expense of Abramis brama.

\section{Conclusions}

1. Seasonal changes in the qualitative and quantitative composition of zoobenthos have a great impact on the food supply of fish.

2. Changes in the bottom fauna of reservoirs affect the species diversity of ichthyofauna.

3. In connection with a change in the hydro-chemical regime, the integrity of the ecosystem and species diversity is disturbed.

4. The bottom fauna of reservoirs, despite minor differences, has many common features.

5. The Karachunovskoye reservoir is distinguished by the richness of bottom fauna, and it is in this reservoir that the most favorable conditions for the development of zoobenthos are formed - the biological supply of the species composition of the benthic fauna.

6 . By using the forage resources of the zoobenthos of small reservoirs, fish productivity can be increased.

7. The qualitative composition of food stocks completely coincides with the nature of the diet of the complex of commercial fish.

8. As a result of the conducted studies of aquatic invertebrates in the inland waters of the Steppe zone of Ukraine, the following conclusion can be drawn - due to the change in the hydrological regime of rivers, and with this the conditions for the existence of aquatic organisms in them, their number fluctuates sharply and the issue of management and control of biological productivity remains relevant and meaningful. In living nature, plant and animal organisms are linked to each other and the environment. Changes in the environment determine the development of organisms, which, in order not to die, adapt to these changes. Any biocenosis as a whole and its constituent structural elements are the result of long-term mutual adaptation, interaction with the environment. Any component of the biocenosis, performing its functions, to one degree or another, communicates with other components and certain elements of the external environment, and this is clearly reflected in our research. The economic effect depends on the relationship of populations with environmental factors and, first of all, on biotic factors with "aborigines" in the new reservoir.

\section{References}

Grinzhevsky, M. V., Sherman, I. M. (2006). Organization of selection-pedigree works on fish-breeding. Kiev, 2006, 338 p.

Gritsinyak, I. I. (2008). Fish farming. Kyiv (in Ukrainian).

Integrated pollution control (1994). Ed. J. A. G. Drake. London, RSC, $102 \mathrm{p}$.

Israel, Yu. A. (1984). Ecology and control of the state of the natural environment. Moscow, Gidromethioizdat (in Russian).

Ivanov, A. P. (2013). Fish farming in natural reservoirs. Moscow, Agropromizdat (in Russian).

Kobyakov, D. O., Remez, A. O., Poleva, Yu. L. (2020). Prehydraulic changes in the middle of the village of Bazavluk along with natural and anthropogenic factors // Issues of steppe forestry and forest reclamation of lands, 49, 94-100 (in Ukrainian).

Poleva, Yu. L. (2005). The current state of research of means of chemical protection of phytocenoses (anthropotechnogenesis, aftereffect, environmental safety). Ecology and Noospherology, 16, 3-4, 249-254 (in Ukrainian).

Sherman, I. M. (1992). Ecology and technology of fish farming in small reservoirs. Kiev, Vishcha school (in Russian).

Zagubizhenko, N. I. (1980). Acclimatization of forage invertebrates in water bodies of Krivoy Rog region. Results and prospects of acclimatization of fish and invertebrates in water bodies of the USSR. Moscow, 49-50 (in Russian).

Zhuravel, P. A. (1947). Acclimatization of forage of LimanCaspian fauna in reservoirs and lakes of the USSR. Dnepropetrovsk, 17-22 (in Russian). 